\title{
Why Does a Teacher Need to Facilitate the Learning? : A Comparative Study
}

\section{Davut Aktepe}

A lecturer of Beder University, and a PhD candidate of European

University, Tirana, Albania

email: daktepe@beder.edu.al

\section{Lokman Coskun}

A lecturer of Beder University, and a PhD candidate of European University, Tirana, Albania emali: Icoskun@beder.edu.al

Doi:10.5901/jesr.2014.v4n2p47

Abstract

The aim of this study is to identify the factors that make students' learning better in educational environment. The qualitative method was utilized in this study to find out due data for explaining the factors for better learning. This study expresses the importance of facilitating and making the learning be loved by the students through comparing the explanations and views of John Dewey and the Prophet Muhammad. Because, the teacher needs to help the students how to learn in learning process and also the teacher should know how to make the lesson be loved by the students, but not to be hated. The data was collected from the written views of John Dewey and the Prophet Muhammad's approach in this regard. The limitation is that we could not make any questionnaire or interviews. If those were done with some professors the reliable data were collected. The results reveal that the teachers should approach the students like mother and father while teaching. Thus, this approach will make students learn easily and also make the students motivation high and better towards learning.

Keywords: Motivation, Approach, facilitate, be loved, learning

\section{Introduction}

Learning requires a teacher to help the students understand the learning materials. What the teachers observe in the learning environment, many students do not stay passive but active.

Thus, the teachers need to create an environment that pushes the students to learn the learning materials. This beneficial environment can give a scope for the students to participate in learning materials. Participation is likely to help the teacher for better guidance that can enhance performance and success of the students.

Firstly, in another word, as the nature of prophet's duties:" Allah has sent a messenger like a teacher". So the profession of prophet was education and training of society, to accept the prophetic mission and make people believe it.

Education should be by knowing the structure of society and era we live, keeping in mind the requirements and needs any improvement activities to be done.

Nowadays students firstly we must make them love the lessons, to help and faceplate them in good manners otherwise student may hate both teacher and lesson and as a result he will not achieve and will fail. Teacher shouldn't behave just as an officer that does his job regarded with the curriculum and after lesson gets away, but behaving as a parent providing them help, love and facilitating things would be more useful during the processing of course.

Of course as it happen usually extremism is not good, even in our students they shouldn't find everything ready, when we help them we should keep the balance otherwise students will become lazy and want to find everything ready. They might thing that we don't need to study hard and whipping effort however our teacher will help us, and could not make mental exercise (think a lot). Again, not helping them and letting them alone to study may push them to pessimism and may not succeeds. They might become despair and then give up.

In this aspect, the soft language, a friendly face and an optimistic heart facilitate students to success in the training course. 


\section{Literature Review}

The "teacher is a facilitator of student learning, and his/her interventions diminish as students progressively take on responsibility for their own learning processes." Hmelo-Silver, C. E., et, al., (2006.p.24). And he adds that "The facilitator guides students in the learning process, pushing them to think deeply, and models the kinds of questions that students need to be asking themselves"

Hmelo-Silver, C. E., et, al., (2006.p.24) expresses that "the facilitator must continually monitor the discussion, selecting and implementing appropriate strategies as needed."

On the other hand "No longer is the teacher seen predominantly as a dispenser of information or walking tape recorder, but rather as a facilitator or manager of the students' learning" and "The teacher's role is not to inform the students but to encourage and facilitate them to learn for themselves using the problem as a focus for the learning" says Crosby, R. H. J. (2000.p.339) and he adds that "The increasing availability and use of learning resource materials also brings with it the need for the teacher as a learning facilitator."

Then he gives more information as follows: "It is the responsibility of the teacher to facilitate student use of the resources by overcoming any deficiencies in the materials and by integrating them into the curriculum." Crosby, R. H. J. (2000.p.339).

"For classroom interaction to be facilitative it must therefore break from this pattern and offer learners greater participation rights which give them the potential to take more initiative and hence responsibility for their own learning." and "facilitator-learner interaction allows the learner to have a larger say in who says what to whom and when. Thus, learners may (or may not) use this freedom to take more responsibility for their own learning." emphasizes Clifton, J. (2006.P.143).

"Teaching presence begins before the course commences as the teacher, acting as instructional designer, plans and prepares the course of studies, and it continues during the course, as the instructor facilitates the discourse and provides direct instruction when required." Anderson, T., at, al.(2001.p.5).

Teacher "emphasizes the personal nature of teacher student interactions. Guides students by asking questions, exploring options, suggesting alter natives, and encouraging them to develop criteria to make informed choices. Overall goal is to develop in students the capacity for independent action and responsibility. Works with students on projects in a consultative fashion and provides much support and encouragement". Grasha, A. F. (1994.p.143).

\section{Discussion}

Regarding approaches and teaching, the following examples appear very meaningful. The prophet's stance on an issue and his actions are in tune with his discourses, the result is seen as extremely positive in the image as a trainer with his companions.

In an example; A companion named Muaviye b. Hakem es-Sulemi says: "I have never seen a teacher who is more beautiful and better in education than the Messenger of Allah, He scolded me, nor beat or insulted". Abu Hurairah (R. A.) says:

In another example; one Bedouin one day pissed in the Prophets (P.B.U.H) mosque. The people that were in mosque got angry they shouted at him and wanted to hit him, and almost they hit him.

There upon the Prophet (P.B.U.H) gave them this command: Leave him, pour a bucket of water where he urinates, and clean. You have been sent as a facilitator, not as complicate.

Otherwise students will hate the course, in this point our Prophets advice is very important for teachers for the behavior they should have towards students;"Make it easier, do not make it difficult, Gospels, don't make them hate".

I think that is important to say and read some of his facilitators training methods and the importance that he has given to Education. The Prophet has attached great importance to education and training. In His action sand words has knowledge, learning, teaching, and he gives very importance to students and teachers. In the hadith literature there are hundreds of hadith that encourage education and training, and also hundreds that revile against ignorance.

Easing thing is not something that can occur immediately of course. To make things easy firstly the trainer or educator must know his students in all aspects. His weak sides, his family and his educational aims and objectives, only in this way you can help him.

Teacher-student relationship in terms of traditional classroom environment has always been an important factor in student's achievement. Teacher should always follow his student's instant responses to lessons. But in web-based 
teaching it's not showed the same convenience. For this reasons we should give basic methods or programs that student can discover their best way to learn. Teachers should design the course in a way to include different methods of teaching forms for student with different methods of learning forms. Educators should endearing, not to hate and must facilitate. Our Prophet (P.B.U.H ) recommends us to ingratiate and facilitate.

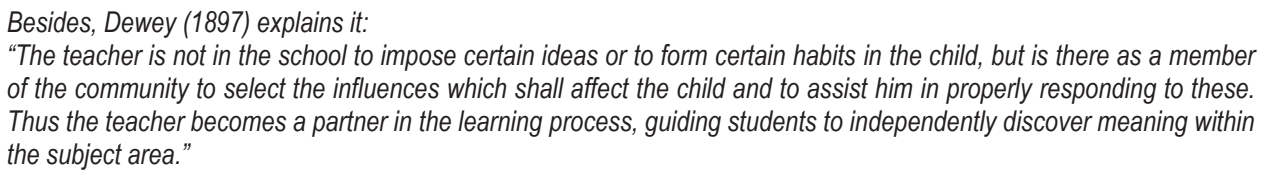

But, there should a balanced relation between the students and the teacher. If the lesson goes on just according to traditional method in which the teacher has a dominant role which shows an authoritarian behavior and the students are like just listeners, or the learning occurs just in student-centered fashion, both of them looks very harmful for not the teacher and the students.

Therefore, the teachers should know the importance of potential flow and find equilibrium in learning process for better performance. Thus, John Dewey says that "we must take our stand with the child and our departure from him. It is not the subject-matter which determines both quality and quantity of learning." (Dewey,(1902). p.13-14). Actually, this situation makes clear the role of the teacher in learning environment.

Teacher's role is a facilitator and facilitating the learning materials according to the understanding level of the students in relation learning materials. But the teacher keeps in mind that there should be a balance between teaching the learning materials and considering the desires, interests and experiences of the particular student in learning environment. Learning and experiential education are related, but not synonymous with experiential learning.

\title{
4. Conclusion
}

If the teachers really know their role and become facilitator, then expected and promising future generations are likely to be educated under the hand of real facilitators (teachers). Because, in case, the teachers are taking the role of facilitators, the students feel themselves very comfortable and ready for learning process. It is clearly known that the students can learn better with facilitating approaches not by force.

\begin{abstract}
As Dewey (1897) explains that:
"Hence it is impossible to prepare the child for any precise set of conditions. To prepare him for the future life means to give him command of himself; it means so to train him that he will have the full and ready use of all his capacities; that his eye and ear and hand may be tools ready to command, that his judgment may be capable of grasping the conditions under which it has to work, and the executive forces be trained to act economically and efficiently. It is impossible to reach this sort of adjustment save as constant regard is had to the individual's own powers, tastes, and interests-say, that is, as education is continually converted into psychological terms."
\end{abstract}

On the other hand, The Prophet Muhammad (P.B.U.H) has advised promoting tolerance and patience and to follow facilitating methods in education, not to use violence and anger. In relation to it, There is a hadith which explaines the importance of facilitating whatever you doing or teaching in real life situations as follows; Anas (May Allah be pleased with him) reported:

The Prophet (p.b.u.h) said, "Make things easy and do not make them difficult, cheer the people up by conveying glad tidings to them and do not repulse (them)." Bukhari and Muslim. (1997).

In fact, facilitating approach creates a scope for both students and teachers not hating from learning/teaching, but loving the learning/teaching process and it also helps the students/teachers learn the learning materials smoothly or teach smoothly, as a result the learning occurs without showing any uninterested and avoidance for the learning materials from both sides teachers and students.

In this regard, the views of the prophet Muhammad and the views of John Dewey go along with each other and help the teachers how to behave in learning environment towards the students for fruitful teaching/learning.

Learning takes place in an environment and learner's perspectives are important to create a congenial learning environment. But, it is not easy to create a positive learning atmosphere, if the teacher does not know how to behave 
towards the students and let them tell their ideas. Because, learning is likely to be fruitful, if the teacher becomes a facilitator and facilitates the learning process.

\section{References}

Anderson, T., Liam, R., Garrison, D. R., \& Archer, W. (2001). Assessing teacher presence in a computer conferencing context. Başar, H. (2006). Sınıf Yönetimi. Ankara: Anı Yayıncılık.

Bukhari and Muslim. (1997). The translation of the meanings of Sahīh Al-Bukhāri: Arabic-English. Vol. 3. Dar-us-Salam, 1997. Arabic/English reference book: Book 1, Hadith 637. Retreived from: http://sunnah.com/riyadussaliheen/1/637

Çelik. V. (2005). Sınıf Yönetimi. Ankara: Nobel Yayın Dağııım.

Demirel, Ö. (1999). Öğretme Sanatı. Ankara: PegemA Yayıncılık.

Clifton, J. (2006). Facilitator talk. ELT journal, 60(2), 142-150.

Crosby, R. H. J. (2000). AMEE Guide No 20: The good teacher is more than a lecturer-the twelve roles of the teacher. Medical teacher, 22(4), 334-347.

Grasha, A. F. (1994). A matter of style: The teacher as expert, formal authority, personal model, facilitator, and delegator. College teaching, 42(4), 142-149.

Hmelo-Silver, C. E., \& Barrows, H. S. (2006). Goals and strategies of a problem-based learning facilitator. Interdisciplinary Journal of Problem-based Learning, 1(1), 4.

John Dewey's famous declaration concerning education. First published in The School Journal, Volume LIV, Number 3 (January 16, 1897), pages 77-80. Retreived on:15/04/2014, from:

http://playpen.meraka.csir.co.za/ acdc/education/Dr_Anvind_Gupa/Learners_Library_7_March_2007/ Resources/books/readings/17.pdf Özden, Y. (2000). Eğitimde Dönüşüm: Eğitimde Yeni Değerler. Ankara: PegemA Yayıncılık.

Sabancı, A. (2008). Sınıf Yönetiminin Temelleri, (Ed. Çelikten, M. Yapılandırmacı Yaklaşıma Göre Sınıf Yönetimi). Ankara: Anı Yayıncilık.

Savaş, B. (2007). Yapılandırmacı Öğrenme. (İçinde: Eğitim Psikolojisi, Edit. Alim Kaya)

Tan, Ş., Kayabaşı, Y. \& Erdoğan, A. (2002). Öğretimi planlama ve değerlendirme. Ankara: Anı Yayıncılık. 